\title{
Response of Circulating Ghrelin Levels to Insulin Therapy in Children with Newly Diagnosed Type 1 Diabetes Mellitus
}

\author{
LEANDRO SORIANO-GUILLÉN, VICENTE BARRIOS, ALFONSO LECHUGA-SANCHO, \\ JULIE A. CHOWEN, AND JESÚS ARGENTE
}

Department of Pediatric Endocrinology and Laboratory of Research, Universidad Autónoma, Hospital Infantil Universitario Niño Jesús, E-28009 Madrid, Spain

\begin{abstract}
Ghrelin is secreted primarily by the stomach, although other tissues such as the pancreas synthesize a minor proportion. The discovery of a new cell type that produces ghrelin in the human pancreas and that this organ expresses GHS-R opens new perspectives in the understanding of the control of glucose metabolism. We have studied 22 children with newly diagnosed type 1 diabetes mellitus at four different points: at diagnosis before insulin therapy, after $48-60 \mathrm{~h}$ of insulin therapy, and after 1 and 4 mo of insulin treatment. At each point circulating levels of ghrelin, leptin, IGF-I, IGF binding protein (IGFBP)-1, IGFBP-2, IGFBP-3, and glucose were determined. Ghrelin levels were significantly decreased at diagnosis $(573 \pm 68 \mathrm{pg} / \mathrm{mL}, p<0.01)$ compared with controls $(867 \pm 38 \mathrm{pg} / \mathrm{mL})$ and remained decreased after insulin therapy (d 2: $595 \pm 68 \mathrm{pg} / \mathrm{mL} ; 1 \mathrm{mo:} 590 \pm$ $61 \mathrm{pg} / \mathrm{mL}$; 4 mo: $538 \pm 67 \mathrm{pg} / \mathrm{mL}$ ) with no differences before or after insulin treatment. There was a negative correlation between ghrelin levels and body mass index at all of the study points, whereas a negative correlation between ghrelin and glucose
\end{abstract}

\section{ABSTRACT}

concentrations was only observed after insulin therapy. No correlation between ghrelin and $\mathrm{HbA} 1 \mathrm{c}$ was found at any point. A positive correlation between ghrelin and IGFBP-1 was found after insulin therapy, but no correlation with other members of the IGF system or leptin was found. In conclusion, these data could indicate a possible link between glucose concentrations and ghrelin; hence, the persisting low ghrelin levels in diabetic children may suggest a defensive mechanism against hyperglycemia. (Pediatr Res 55: 830-835, 2004)
Abbreviation
GHS-R, GH secretagogue receptor
IGFBP-1, IGF binding protein-1
IGFBP-2, IGF binding protein-2
IGFBP-3, IGF binding protein-3
HbA1C, glycosilated $\mathrm{Hb}$
SDS, SD score (Z score)

The recent discovery of ghrelin, an acylated 28 amino acid peptide (1), has added new perspectives to our understanding of the control of food intake, energy balance, and growth. Ghrelin is secreted primarily by the stomach and duodenum, although a minor proportion of ghrelin synthesis occurs in other sites such as the hypothalamus, pituitary, and lung. Ghrelin can bind to two different receptors (2), GHS-R1a, involved in the control of GH secretion, and GHS-R1b whose function remains unknown. Recent reports $(3,4)$ describe a new cell type in the human pancreas that produces ghrelin. The pancreas also expresses GHS-R (2); hence, in addition to stimulating $\mathrm{GH}$ secretion (5) and controlling food intake, fat utilization, and fat synthesis $(6-8)$, ghrelin could play an

Received August 6, 2003; accepted December 10, 2003.

Correspondence: Jesús Argente, M.D., Ph.D., Department of Pediatric Endocrinology and Laboratory of Research, Hospital Infantil Universitario Niño Jesús, Avda. Menéndez Pelayo, 65, E-28009 Madrid, Spain; e-mail: argentefen@terra.es

Supported by the Fundación Endocrinología y Nutrición.

DOI: 10.1203/01.PDR.0000120679.92416.70 important role in glucose and insulin metabolism. However, controversial data exist concerning the influence of ghrelin on glucose and insulin levels. Although some authors report that ghrelin stimulates insulin secretion $(9,10)$, others suggest that it reduces insulin secretion (11-13). There are also controversial data related to the influence of glucose administration on ghrelin levels $(14,15)$ and the changes in ghrelin levels after insulin administration $(16,17)$. However, it is clear that ghrelin administration produces hyperglycemia $(12,13)$. This ghrelininduced rise in glucose levels is unrelated to a decrease in insulin secretion as the decline in insulin often follows the hyperglycemia. Furthermore, it does not reflect an increase in glucagon secretion (13).

In Spain, the incidence of type 1 diabetes mellitus is 11.3 per 100,000 children below 15 y of age (18). This chronic disease is associated with alterations in the GH-IGF system, which are partially accounted for by changes in metabolic control and are also affected by pubertal status (19). It is well known that these patients have decreased IGF-I and elevated IGFBP-1 and 
IGFBP-2 serum levels, especially in those with inadequate metabolic control, whereas IGFBP-3 levels do not differ with respect to normal controls $(19,20)$. After insulin administration, an increase in IGF-I, a decrease in IGFBP-1, and no change in IGFBP-3 levels is observed (21). These disturbances may play a role in the pathogenesis of growth impairment in children with poorly controlled type 1 diabetes mellitus and in the development of secondary complications (19). Leptin, a hormone encoded by the $o b$ gene, acts as a hormonal feedback signal at the level of the hypothalamus to regulate fat stores (22). Leptin and ghrelin are thought to exert opposite effects on metabolism (6-8). Leptin is decreased in newly diagnosed type 1 diabetic patients and increases after insulin therapy. This increase is independent of changes in body weight and is probably due to the stimulatory effect of insulin on leptin production $(23,24)$.

To our knowledge, there are no published data concerning ghrelin levels in patients with type 1 diabetes mellitus at diagnosis and after insulin therapy. To further investigate the role of ghrelin in glucose and insulin metabolism, we analyzed 1) plasma ghrelin levels in children with type 1 diabetes mellitus at diagnosis and after insulin therapy, 2) the relationship between ghrelin and anthropometric data, and 3) the correlation between ghrelin and leptin, IGF-I, IGFBP-1, IGFBP-2, IGFBP-3, and glucose concentrations throughout the study.

\section{SUBJECTS AND METHODS}

Subjects. Twenty-two children (10 boys and 12 girls), aged $6.44 \pm 0.76 \mathrm{y}$, admitted to the Hospital Infantil Universitario Niño Jesús with newly-diagnosed type 1 diabetes mellitus were studied during $1 \mathrm{y}$. All subjects had abrupt diabetes onset with classical symptoms. Patients with ketoacidosis $(n=9)$, as evidenced by an arterial $\mathrm{pH}<7.3$, plasma glucose $>300$ $\mathrm{mg} / \mathrm{dL}$, and ketonuria, were treated with i.v. fluids and continuous insulin infusion according to our standard protocol. The insulin dose ranged between 0.05 and $0.1 \mathrm{IU} / \mathrm{kg} / \mathrm{h}$ for at least $24 \mathrm{~h}$. Five patients were treated with continuous insulin infusion during $48 \mathrm{~h}$. Four patients received a continuous insulin infusion during $24 \mathrm{~h}$ and then s.c. insulin from 24 to $48 \mathrm{~h}$. The remaining subjects were started on short-acting s.c. insulin injections every $4 \mathrm{~h}$ for the first $24 \mathrm{~h}$, with an insulin dose ranging between 0.6 and $1 \mathrm{IU} / \mathrm{kg} / \mathrm{d}$. After $48-60 \mathrm{~h}$, depending on the clinical situation of the child, patients were started on a split-mix regimen of intermediate and short-acting insulin administered s.c. The nondiabetic control group consisted of 37 (16 boys and 21 girls) healthy children at Tanner stage I who were referred to our division for suspected endocrine abnormalities and were found to be normal, with height, weight, and body mass index (BMI) between \pm 1 SDS according to our Spanish standards. They had a mean age of $7.13 \pm 0.49 \mathrm{y}$, with a mean BMI SDS of $0.15 \pm 0.40$, a mean height SDS of 0.04 \pm 0.14 , and a mean weight SDS of $0.07 \pm 0.15$.

Blood samples for ghrelin measurements were collected at presentation before insulin therapy was initiated (diabetes mellitus time point 1: DM 1), 48-60 h after insulin therapy (diabetes mellitus time point 2: DM 2), and after 1 mo (dia- betes mellitus time point 3: DM 3) and 4 mo (diabetes mellitus time point 4: DM 4) of follow-up. All blood samples were obtained after overnight fasting in control subjects. In diabetic patients, all blood samples were obtained after overnight fasting except at the moment of the diabetic debut (d 0$)$, when the samples were obtained at the moment of presentation to avoid any delay in beginning insulin treatment. Patients who had eaten during the $3 \mathrm{~h}$ previous to starting insulin therapy (d 0 ) were excluded from the study. Blood samples were drawn into chilled tubes containing EDTA $(1 \mathrm{mg} / \mathrm{mL})$ plus aprotinin $(500$ $\mathrm{U} / \mathrm{mL}$ ). The samples were centrifuged and stored at $-80^{\circ} \mathrm{C}$ until assayed.

All subjects were informed of the purpose of the study and parents or guardians gave consent as required by the local human ethics committee. This study was approved by the local human ethics committee.

Biochemical measurements. Plasma ghrelin levels were measured by a commercial RIA assay (Phoenix Pharmaceutical, Inc., Belmont, CA, U.S.A.) using a polyclonal antibody that recognizes octanoylated and nonoctanoylated ghrelin and ${ }^{125} \mathrm{I}$-ghrelin as a tracer molecule. The intra- and interassay coefficients of variation were $5.0 \%$ and $11.2 \%$, respectively. Assay sensitivity was $12 \mathrm{pg} / \mathrm{mL}$.

HbA1c, IGF-I, IGFBP-1, IGFBP-2, IGFBP-3, insulin, and leptin were measured as previously reported $(20,25-28)$.

Plasma glucose was measured by the glucose oxidase method on a Beckman glucose analyzer (Beckman Coulter, Fullerton, CA, U.S.A.).

Statistics. All data are reported as the mean \pm SEM. When two experimental groups were compared, $t$ test was applied. For more than two experimental groups, analysis was performed by ANOVA for repeated measures, followed by Scheffé's $\mathrm{F}$ test. Multiple regression analysis was performed to determine the overall interaction of the parameters studied, followed by partial correlation analysis. Stepwise multiple regression analysis was performed to determine the effect of the other independent variables on ghrelin. A value of $p<0.05$ was chosen as the level of significance.

\section{RESULTS}

Anthropometric and clinical data. Our data show a significant increase in BMI in diabetic patients during the study period. There was also a significant decrease in glucose levels, $\mathrm{HbA1c}$, and insulin dose throughout the study (see Table 1).

Laboratory results. Ghrelin levels were significantly decreased in newly diagnosed type 1 diabetes (DM 1): $573 \pm 68$ $\mathrm{pg} / \mathrm{mL}$ (range, 162-1230) compared with controls: $867 \pm 38$ $\mathrm{pg} / \mathrm{mL}$ (range, 347-1260) $(p<0.01)$.

The study group of 22 patients was heterogeneous regarding the form of insulin administration until after the second blood sample was drawn for ghrelin analysis (d 2). However, no significant differences in ghrelin levels were found between patients who received i.v. insulin, s.c. insulin, or i.v./s.c. insulin therapy. Forty-eight to sixty hours after the onset of diabetes, mean ghrelin levels at study time-point 2 (DM2) in the 12 patients that received s.c. insulin therapy were $519 \pm 89$ $\mathrm{pg} / \mathrm{mL}$; in the five patients treated with insulin perfusion, 623 
Table 1. Anthropometric and clinical data of the type 1 diabetes patients during the study

\begin{tabular}{|c|c|c|c|c|c|c|}
\hline & Height (SDS) & Weight (SDS) & BMI (SDS) & $\begin{array}{l}\text { Glycemia } \\
(\mathrm{mg} / \mathrm{dL})\end{array}$ & $\begin{array}{l}\text { Insulin dose } \\
\text { (UI/kg/d) s.c. }\end{array}$ & HbA1c (\%) \\
\hline Day 0 & - & - & - & $373 \pm 27$ & - & - \\
\hline Day 2 & $0.35 \pm 0.29$ & $-0.42 \pm 0.21$ & $-0.97 \pm 0.16$ & $178 \pm 16^{* *}$ & $0.75 \pm 0.03$ & $11.06 \pm 0.45$ \\
\hline $4 \mathrm{mo}$ & $0.16 \pm 0.44$ & $0.04 \pm 0.34$ & $-0.09 \pm 0.28^{*}$ & $176 \pm 22 * *$ & $0.42 \pm 0.06^{*}$ & $7.34 \pm 0.26^{*}$ \\
\hline
\end{tabular}

$* p<0.05$, ANOVA; $* * p<0.01$, ANOVA.

$\pm 87 \mathrm{pg} / \mathrm{mL}$; and in the patients treated with insulin perfusion $(24 \mathrm{~h})$ and then s.c. insulin ( $24 \mathrm{~h}$ more), $598 \pm 148 \mathrm{pg} / \mathrm{mL}$. Hence, the results at DM 2 were combined for all 22 patients. After collection of the second blood sample for ghrelin analysis, all patients were started on a split-mix regimen of intermediate and short acting insulin s.c.

Even after insulin therapy, mean ghrelin levels remained decreased compared with controls: d 2 (DM 2): $595 \pm 68$ $\mathrm{pg} / \mathrm{mL}$ (range, 218-1220); 1 mo (DM 3): $590 \pm 61 \mathrm{pg} / \mathrm{mL}$ (range, 245-1215); 4 mo (DM 4): $538 \pm 67 \mathrm{pg} / \mathrm{mL}$ (range, 275-1145). No differences were found in mean ghrelin levels before or after insulin therapy in type 1 diabetic patients (Fig. $1 A)$.

Leptin levels were decreased in diabetic patients at diagnosis, with a rapid increase after insulin therapy, such that $48-60$ $\mathrm{h}$ after beginning insulin therapy (DM 2) there was no significant difference from controls (Fig. 1B). IGF-I levels were also decreased at diagnosis and reached normal values after 1 mo of insulin treatment (Fig. 1C). IGFBP-3 levels were normal at diagnosis and did not change with insulin treatment (Fig. 1D). IGFBP-1 levels were increased at all study points (Fig. 1E), whereas IGFBP-2 levels normalized after 1 mo of therapy (Fig. $1 F)$.

Insulin dose and ghrelin levels. We found no effect of insulin dosage on ghrelin levels. Patients who received $<0.6$ $\mathrm{UI} / \mathrm{kg} / \mathrm{d}$ on a split-mix regimen of intermediate and shortacting insulin s.c. at $1 \mathrm{mo}$ (insulin dose, $0.41 \pm 0.04$ ) and $4 \mathrm{mo}$ of treatment (insulin dose, $0.42 \pm 0.06$ ) had a mean ghrelin level of $511 \pm 66 \mathrm{pg} / \mathrm{mL}$. Those patients who received $>0.6$ $\mathrm{UI} / \mathrm{kg} / \mathrm{d}$ had a mean ghrelin level of $501 \pm 40 \mathrm{pg} / \mathrm{mL}$. Hence, there was no difference in mean ghrelin levels despite a significant difference between these groups in mean glucose levels $(135 \pm 8 \mathrm{mg} / \mathrm{dL}$ versus $186 \pm 11 \mathrm{mg} / \mathrm{dL}$, respectively; $p<0.001)$.

Correlations between ghrelin and BMI, glucose concentrations, and HbAlc. In diabetic patients there was a negative correlation between ghrelin levels and BMI throughout the study. A similar correlation was found in the control group (Fig. 2A). Ghrelin levels were negatively correlated with glucose levels in controls and in diabetic patients after insulin administration (Fig. 2B). No correlation between ghrelin levels and $\mathrm{HbA} 1 \mathrm{C}$ was found at diagnosis $[r=-0.03(\mathrm{NS})]$ or after 4 mo of treatment $[r=-0.05(\mathrm{NS})]$.

Correlations between ghrelin and IGF-I, IGFBP-1, IGFBP-2, IGFBP-3, and leptin levels. No correlation between ghrelin and IGF-I, IGFBP-3, or leptin levels was found (Table 2). A positive correlation between ghrelin and IGFBP-2 was found after $2 \mathrm{~d}$ of insulin treatment, but this correlation was not significant at later time points. A significant positive correla- tion was found between ghrelin and IGFBP-1 levels in controls and in diabetic patients after insulin therapy, but not in diabetic patients at diagnosis (Fig. 2C).

\section{DISCUSSION}

Although previous reports suggest an important role for ghrelin in glucose metabolism (9-17), the exact implication of this peptide remains unknown. In addition, there are no data published on ghrelin levels in children with type 1 diabetes. To further understand the role of ghrelin in diabetic patients, we analyzed plasma ghrelin, leptin, IGF-I, IGFBP-1, IGFBP-2, and IGFBP- 3 in a cohort of children with type 1 diabetes at the time of diagnosis and after insulin therapy at three different time points.

We found ghrelin levels to be decreased in diabetic children and to remain so even after insulin therapy. As insulin (17) and high BMI $(29,30)$ are suggested to inhibit ghrelin secretion, one might predict that diabetic patients without insulin and with low BMI should have elevated ghrelin levels. On the contrary, ghrelin levels were decreased and did not return to normal values despite insulin therapy and BMI recuperation. Glucose is suggested to inhibit ghrelin secretion (14). Hence, one might hypothesize that the high glucose levels found at the debut of diabetes inhibit ghrelin secretion. However, no correlation between ghrelin levels and glucose concentrations was found at this moment of the study.

Ghrelin has been shown to stimulate hyperglycemia $(12,13)$. This effect is unrelated to the decrease in insulin levels, as this decrease often occurs after the increase in glucose concentrations. Furthermore, the rise in plasma glucose levels does not reflect an increase in glucagon secretion. To explain the hyperglycemic effect of ghrelin, a direct glycogenolytic action at the hepatic level could be hypothesized. This is probably mediated through a GHS-R that is not type 1a, as synthetic GHS do not modify glucose concentrations (12). Indeed, there is a negative correlation between ghrelin and glucose concentrations throughout normal development with no relationship to basal insulin levels (31). Here we show that this relationship is also present in diabetic patients after insulin therapy. Taken together, these data suggest that ghrelin has an important relationship with glucose concentrations and this could be independent of insulin. Ghrelin could have a direct hyperglycemic effect via glycogenolysis (13) and at the same time, ghrelin-producing cells could be directly influenced by glucose levels (14). Hence, in situations of elevated glucose concentrations the organism may respond by decreasing ghrelin levels so that it does not contribute to a further increase in glucose concentrations. 
A

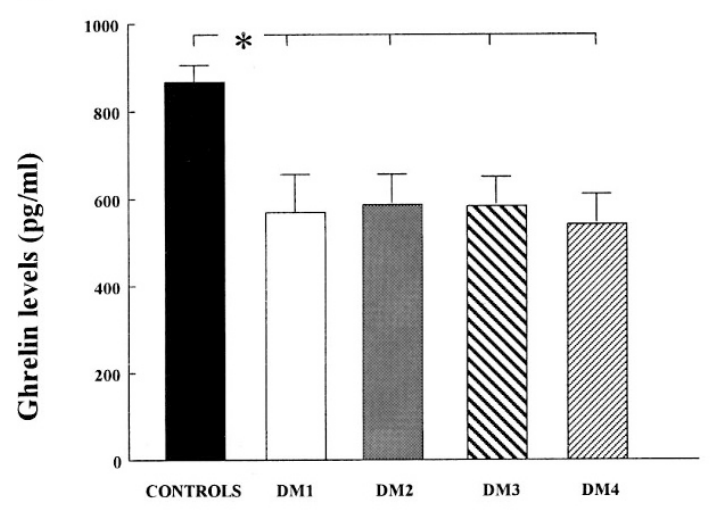

C

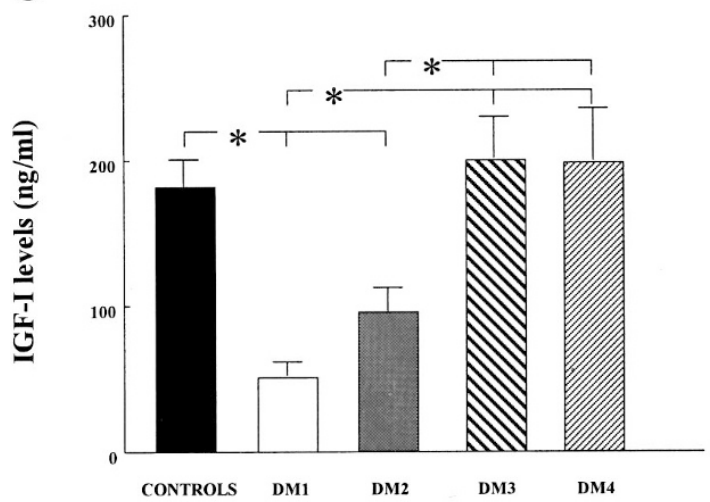

E

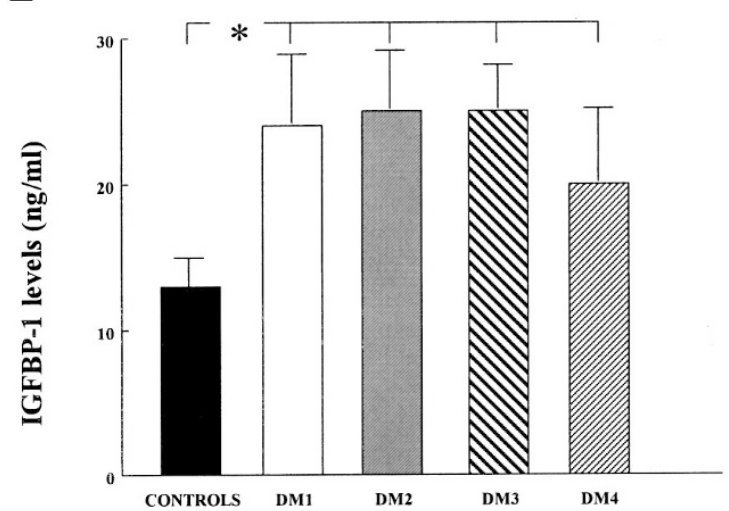

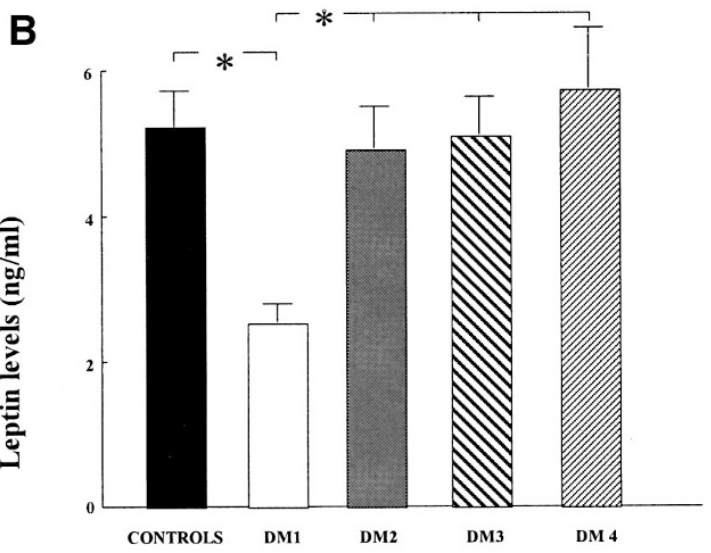

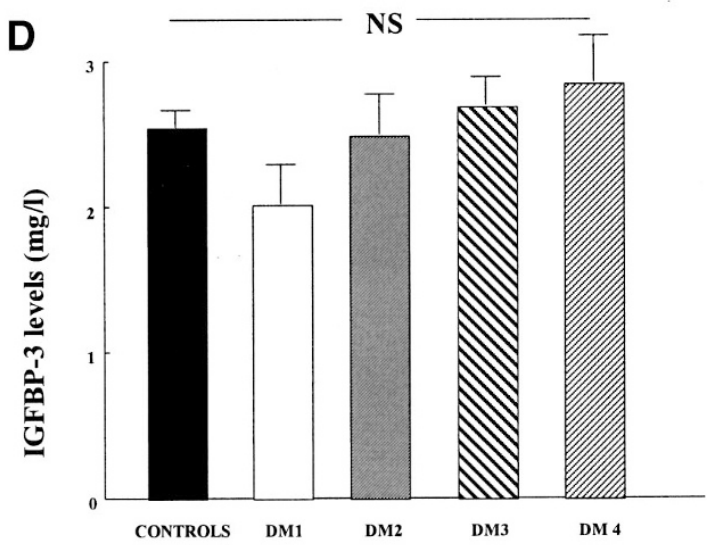

$\mathbf{F}$

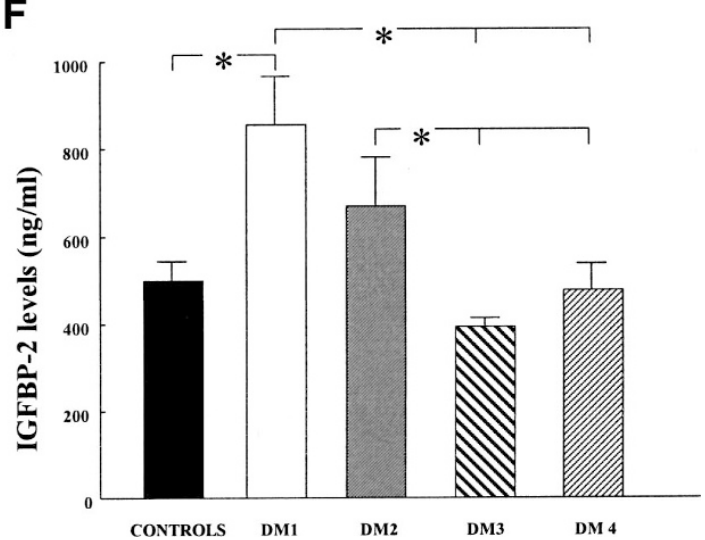

Figure 1. Schematic representation of the mean ( \pm SEM) serum levels of ghrelin $(A)$, leptin $(B)$, IGF-I $(C)$, IGFBP-3 $(D)$, IGFBP-1 $(E)$ and IGFBP-2 $(F)$ in children with type 1 diabetes mellitus $(n=22)$ and age-matched controls $(n=37)$. DM 1: children with type 1 diabetes mellitus at diagnosis $(n=22)$; DM 2: children with type 1 diabetes mellitus after $48-60 \mathrm{~h}$ of insulin treatment $(n=22)$; DM 3 : children with type 1 diabetes mellitus after 1 mo of insulin treatment $(n=22)$; DM 4: children with type 1 diabetes mellitus after 4 mo of insulin treatment $(n=22) .{ }^{*} p<0.01$.

The negative correlation between ghrelin and glucose concentrations found in normal controls is observed in diabetic patients only after insulin therapy; however, no correlation between ghrelin levels and $\mathrm{HbA1C}$ was found. These data suggest that ghrelin levels could be influenced more by acute than chronic changes in plasma glucose concentrations.

One of the main actions of exogenous ghrelin is to stimulate appetite (6-8); however, in young children it is difficult to accurately evaluate appetite. Ishii and co-workers (32) found that streptozotocin-induced diabetic rats had a marked increase in circulating ghrelin levels, suggesting that in concert with decreased leptin levels, stomach-derived ghrelin contributes to the diabetic hyperphagia. It is unlikely that high plasma glucose and/or low insulin levels stimulate ghrelin secretion; however, increased ghrelin levels could be mediated by the reduced plasma $\mathrm{GH}$ and/or leptin levels. In contrast to rats, diabetic humans have a hypersecretory pattern of $\mathrm{GH}$, suggesting that the decrease in ghrelin levels is not GH mediated. 


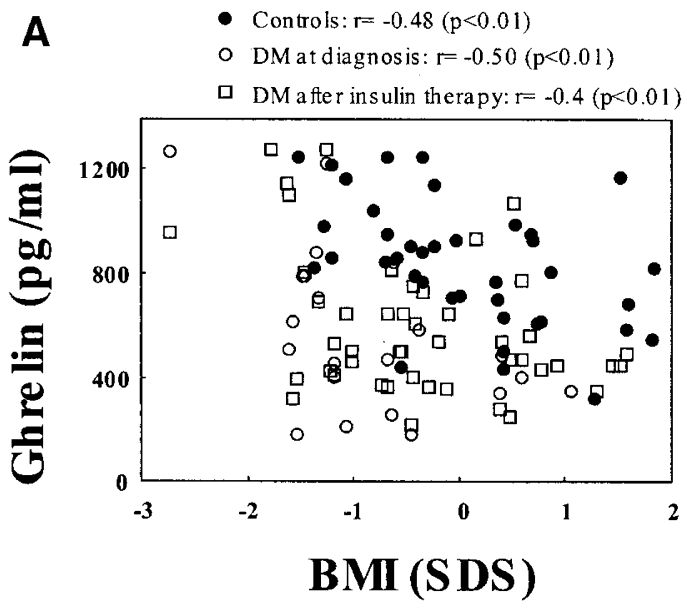
B - Controls: $\mathrm{r}=-0.53(\mathrm{p}<0.05)$
○ DMat diagnosis: $\mathrm{r}=-0.04$ (NS)
$\checkmark$ DM a fter insulin the rapy: $r=-0.43(p<0.01)$

C Controls: $r=0.49(\mathrm{p}<0.01)$

$\square$ DM after insulin the rpay $r=0.54(p<0.001)$
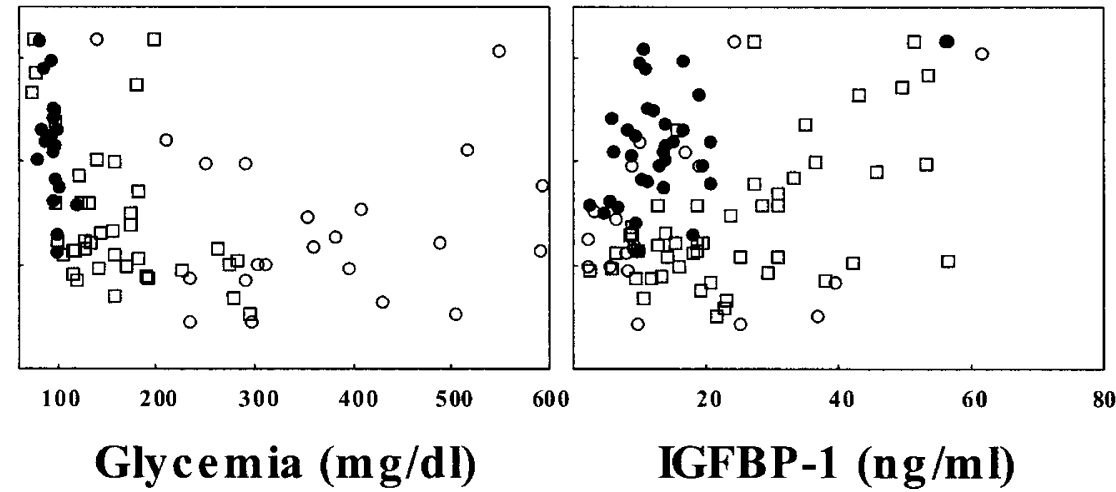

Figure 2. (A) Linear regression analysis between BMI and ghrelin levels in controls (closed circle) and in diabetic patients at diagnosis (open circle) and after insulin therapy (open square). Correlation coefficients and $p$ values are represented for each analysis. $(B)$ Linear regression analysis between glucose concentrations and ghrelin levels in controls (closed circle) and in diabetic patients at diagnosis (open circle) and after insulin therapy (open square). Correlation coefficients and $p$ values are represented for each analysis. (C) Linear regression analysis between IGFBP-1 and ghrelin levels in controls (closed circle) and in diabetic patients at diagnosis (open circle) and after insulin therapy (open square). Correlation coefficients and $p$ values are represented for each analysis.

Table 2. Correlations between ghrelin and IGF-I, IGFBP-1, IGFBP-2, IGFBP-3, leptin, glucose levels, and BMI in the four steps of the study

\begin{tabular}{|c|c|c|c|c|c|}
\hline & \multicolumn{5}{|c|}{$r$ Values } \\
\hline & Day 0 & Day 2 & $1 \mathrm{mo}$ & $4 \mathrm{mo}$ & Controls \\
\hline Ghrelin vs IGF-I & $-0.22(\mathrm{NS})$ & $-0.40(\mathrm{NS})$ & $-0.20(\mathrm{NS})$ & $-0.40(\mathrm{NS})$ & $-0.10(\mathrm{NS})$ \\
\hline Ghrelin $v s$ IGFBP-2 & 0.04 (NS) & $0.75^{* *}$ & $0.40(\mathrm{NS})$ & 0.34 (NS) & 0.40 (NS) \\
\hline Ghrelin $v s$ IGFBP-3 & $-0.17(\mathrm{NS})$ & $-0.44(\mathrm{NS})$ & 0.33 (NS) & $-0.14(\mathrm{NS})$ & $-0.11(\mathrm{NS})$ \\
\hline Ghrelin $v s$ leptin & -0.40 (NS) & $-0.01(\mathrm{NS})$ & -0.21 (NS) & $-0.02(\mathrm{NS})$ & $-0.12(\mathrm{NS})$ \\
\hline
\end{tabular}

$* p<0.05 ; * * p<0.01 ; * * * p<0.001$.

Patients with hyperthyroidism have hyperphagia and low circulating ghrelin levels, suggesting that circulating ghrelin is not the mediator of the hyperphagia in this condition (33). Likewise, in diabetic patients it appears that ghrelin is not the main factor controlling appetite. As previously reported by others $(29,30)$, we found a negative correlation between ghrelin levels and BMI in diabetic patients throughout the study. This suggests that ghrelin, apart from its role in glucose metabolism, has an important function in the control of metabolism.

The pathophysiological mechanisms involved in the alterations of the GH axis in diabetic patients remain unknown. Low serum GH binding protein (GHBP) levels in diabetic patients, in addition to elevated GH levels and low serum IGF-I concentrations, indicate a certain degree of GH resistance. These patients also have elevated IGFBP-1 levels, which could contribute to decrease the biologic activity of IGF-I. Hence, the low levels and biologic activity of IGF-I could be one of the principal elements contributing to the $\mathrm{GH}$ hypersecretion in patients with type 1 diabetes (20). Ghrelin is a potent stimulator of $\mathrm{GH}$ secretion (5), and $\mathrm{GH}$ may have a negative feedback effect on ghrelin. The high GH levels could therefore contribute to the suppression of ghrelin levels. However, after insulin therapy and with normal metabolic control diabetic patients no longer exhibit GH resistance $(19,20)$, although ghrelin levels remain low. No correlation between ghrelin levels and IGF-I or IGFBP-3, both GH dependent proteins, was observed during this longitudinal study, although a significant correlation between ghrelin and IGFBP-1 was found. This positive correlation between ghrelin and IGFBP-1 exists from fetal life through Tanner stage V (31) and after weight normalization in obese children and anorexic adolescents (34). Like ghrelin levels, IGFBP-1 levels decrease during childhood until adulthood (25) and vary markedly during the day in relation to the metabolic status in a GH independent manner (35). In addition, it is thought that IGFBP-1 levels partially depend on insulin levels $(26,27)$. These data suggest a possible relationship between ghrelin and IGFBP-1, but the physiologic significance of this remains to be elucidated.

As reported previously by others $(23,24)$, we found leptin levels to be decreased in newly diagnosed type 1 diabetes patients and to increase after insulin therapy. This increase is independent of changes in body weight and is probably due to the stimulatory effect of insulin on leptin production. On the contrary, ghrelin levels did not change after insulin therapy and did not correlate with leptin levels at any time of the study, suggesting that these two hormones have independent control mechanisms.

In conclusion, the persisting low ghrelin levels in diabetic children after insulin therapy may indicate a defensive mech- 
anism against hyperglycemia. These data and the negative relationship observed between ghrelin and glucose levels regardless of insulin dosage could indicate a link between plasma glucose concentrations and ghrelin levels.

\section{REFERENCES}

1. Kojima M, Hosoda H, Date Y, Nakazato M, Matsuo H, Kangawa K 1999 Ghrelin is a growth-hormone-releasing acylated peptide from stomach. Nature 402:656-660

2. Gnanapavan S, Kola B, Bustin SA, Morris DG, McGee P, Fairclough P, Bhattacharya S, Carpenter R, Grossman AB, Korbonits M 2002 The tissue distribution of the mRNA of ghrelin and subtypes of its receptor, GHS-R in humans. J Clin Endocrinol Metab 87:2988-2991

3. Wierup N, Svensson H, Mulder H, Sundler F 2002 The ghrelin cell: a novel developmentally regulated islet cell in the human pancreas. Regul Pept 107:63-69

4. Rindi G, Necchi V, Savio A, Torsello A, Zoli M, Locatelli V, Raimondo F, Cocchi D, Solcia E 2002 Characterisation of gastric ghrelin cells in man and other mammals: studies in adult and fetal tissues. Histochem Cell Biol 117:511-519

5. Arvat E, Maccario M, Di Vito L, Broglio F, Benso A, Gottero C, Papotti M, Muccioli G, Dieguez C, Casanueva FF, Deghenghi R, Camanni F, Ghigo E 2001 Endocrine activities of ghrelin, a natural growth hormone secretagogue (GHS), in humans: comparison and interactions with hexarelin, a non natural peptidyl GHS, and GHreleasing hormone. J Clin Endocrinol Metab 86:1169-1174

6. Tschop M, Smiley DL, Heiman ML 2000 Ghrelin induces adiposity in rodents. Nature 407:908-913

7. Nakazato M, Murakami N, Date Y, Kojima M, Matsuo H, Kangawa K, Matsukura S 2001 A role for ghrelin in the central regulation of feeding. Nature 409:194-198

8. Wren AM, Seal LJ, Cohen MA, Brynes AE, Frost GS, Murphy KG, Dhillo WS, Ghatei MA, Bloom SR 2001 Ghrelin enhances appetite and increase food intake in humans. J Clin Endocrinol Metab 86:5992-5995

9. Adeghate E, Ponery AS 2002 Ghrelin stimulates insulin secretion from the pancreas of normal and diabetic rats. J Neuroendocrinol 14:555-560

10. Lee HM, Wang G, Englander EW, Kojima M, Greeley Jr GH 2002 Ghrelin, a new gastrointestinal endocrine peptide that stimulates insulin secretion: enteric distribution, ontogeny, influence of endocrine and dietary manipulations. Endocrinology 143:185-190

11. Egido EM, Rodríguez-Gallardo J, Silvestre RA, Marco J 2002 Inhibitory effect of ghrelin on insulin and pancreatic somatostatin secretion. Eur J Endocrinol 146:241 244

12. Broglio F, Arvat E, Benso A, Gottero C, Muccioli G, Papotti M, van der Lely AJ, Deghenghi R, Ghigo E 2001 Ghrelin, natural GH secretagogue produced by the stomach, induces hyperglycemia and reduces insulin secretion in humans $\mathrm{J}$ Clin Endocrinol Metab 86:5083-5086

13. Broglio F, Benso A, Castiglioni C, Gottero C, Prodam F, Destefanis S, Gauna C, Van der Lely AJ, Deghenghi R, Bo M, Arvat E, Ghigo E 2003 The endocrine response to ghrelin as a function of gender in humans in young and elderly subjects. J Clin Endocrinol Metab 88:1537-1542

14. Shiiya T, Nakazato M, Mizuta M, Date Y, Mondal MS, Tanaka M, Nozoe S, Hosoda H, Kangawa K, Matsukura S 2002 Plasma ghrelin levels in lean and obese humans and the effect of glucose on ghrelin secretion. J Clin Endocrinol Metab 87:240-244

15. Schaller G, Schmidt A, Pleiner J, Woloszczuk W, Wolzt M, Luger A 2003 Plasma ghrelin concentrations are not regulated by glucose or insulin: a double-blind, placebo-controlled crossover clamp study. Diabetes 52:16-20

16. Caixas A, Bashore C, Nasw W, Pi-Sunyer F, Laferre B 2002 Insulin, unlike food intake, does not suppress ghrelin in human subjects J Clin Endocrinol Metab 87: 1902-1906
17. Saad MF, Bernaba B, Hwu CM, Jinagouda S, Fahmi S, Kogosov E, Boyadjian R 2002 Insulin regulates plasma ghrelin concentration. J Clin Endocrinol Metab 87:39974000

18. Serrano-Ríos M, Moy CS, Martín Serrano R, Minuesa A, Tomas ME, Zarandieta G, Herrera J 1990 Incidence of type 1 (insulin-dependent) diabetes mellitus in subjects 0-14 years of age in the Comunidad of Madrid, Spain. Diabetologia 33:422-424

19. Strasser-Vogel B, Blum WF, Past R, Kessler U, Hoeflich A, Meiler B, Kiess W 1995 Insulin-like growth factor (IGF)-I and -II and IGF-Binding Proteins-1,-2 and -3 in children and adolescents with diabetic mellitus: correlation with metabolic control and height attainment. J Clin Endocrinol Metab 80:1207-1213

20. Muñoz MT, Barrios V, Pozo J, Argente J 1996 Insulin-like growth factor I, its binding proteins 1 and 3 , and growth hormone-binding protein in children and adolescents with insulin-dependent diabetes mellitus: clinical implications. Pediatr Res 39:992998

21. Brismar K, Fernqvist-Forbes E, Wahren J, Hall K 1994 Effect of insulin on the hepatic production of insulin-like growth factor-binding protein-1 (IGFBP-1), IGFBP-3, and IGF-I in insulin-dependent diabetes. J Clin Endocrinol Metab 79:872-878

22. Zhang Y, Proenca R, Maffei M, Barone M, Leopold L, Friedman JM 1994 Positional cloning of the mouse obese gene and its human homologue. Nature 372:425-432

23. Hanaki K, Becker DJ, Arslanian SA 1999 Leptin before and after insulin therapy in children with new-onset type 1 diabetes. J Clin Endocrinol Metab 84:1524-1526

24. Hathout EH, Sharkey J, Racine M, Ahn D, Mace JW, Saad MF 1999 Changes in plasma leptin during the treatment of diabetic ketoacidosis. J Clin Endocrinol Metab $84: 4545-4548$

25. Argente J, Barrios V, Pozo J, Muñoz MT, Hervás F, Stene M, Hernandez M 1993 Normative data for insulin-like growth factors (IGFs), IGF-binding proteins, and growth hormone-binding protein in a healthy Spanish pediatric population: age- and sex-related changes. J Clin Endocrinol Metab 77:1522-1528

26. Argente J, Caballo N, Barrios V, Pozo J, Muñoz MT, Chowen JA, Hernandez M 1997 Multiple endocrine abnormalities of the growth hormone and insulin-like growth factor axis in prepuberal children with exogenous obesity: effect of short and long-term weight reduction. J Clin Endocrinol Metab 82:2076-2083

27. Argente J, Caballo N, Barrios V, Muñoz MT, Pozo J, Chowen JA, Morande G, Hernandez M 1997 Multiple endocrine abnormalities of the growth hormone and insulin-like growth factor axis in patients with anorexia nervosa: effect of short- and long-term weight recuperation. J Clin Endocrinol Metab 82:2084-2092

28. Argente J, Barrios V, Chowen JA, Sinha MK, Considine RV 1997 Leptin plasma levels in healthy Spanish children and adolescents, children with obesity, and adolescents with anorexia nervosa and bulimia nervosa. J Pediatr 131:833-838

29. Otto B, Cuntz U, Fruehauf E, Wawarta R, Folwaczny C, Riepl RL, Heiman ML, Lehnert P, Fichter M, Tschop M 2001 Weight gain decreases elevated plasma ghrelin concentrations of patients with anorexia nervosa. Eur J Endocrinol 145:669-673

30. Tolle V, Kadem M, Bluet-Pajot MT, Frere D, Foulon C, Bossu C, Dardennes R, Mounier C, Zizzari P, Lang F, Epelbaum J, Estour B 2003 Balance in ghrelin and leptin plasma levels in anorexia nervosa patients and constitutionally thin women. J Clin Endocrinol Metab 88:109-116

31. Soriano-Guillen L, Barrios V, Chowen JA, Sanchez I, Vila S, Quero J, Argente J 2004 Ghrelin levels from fetal life through early adulthood: relationships with endocrine, metabolic and anthropometric measures. J Pediatr 144:30-35

32. Ishii S, Kamegai J, Tamura H, Shimizu T, Sugihara H, Oikawa S 2002 Role of ghrelin in streptozotocin-induced diabetes hyperphagia. Endocrinology 143:4934-4937

33. Riis AL, Hansen TK, Moller N, Weeke J, Jorgensen JO 2003 Hyperthyroidism is associated with suppressed circulating ghrelin levels. J Clin Endocrinol Metab $88: 853-857$

34. Soriano-Guillen L, Barrios V, Campos-Barros A, Argente J 2004 Ghrelin levels in obesity and anorexia nervosa: effect of weight reduction or recuperation. J Pediatr $144: 36-42$

35. Cotterill AM, Cowell CT, Baxter RC, McNeill D, Silinik M 1988 Regulation of the growth hormone-independent growth factor binding protein in children. J Clin Endocrinol Metab 67:882-887 